\section{EMBRYAIDDLE \\ Aeronautical University}

SCHOLARLY COMMONS
International Journal of Aviation, Aeronautics, and Aerospace

7-17-2018

\title{
The perceived value of frequent flyer program benefits among Australian travelers
}

Yi Gao

Swinburne University of Technology, yigao@purdue.edu

Madeline Carrigg

Swinburne University of Technology, Madeline.Carrigg@jetstar.com

Robert Lewinski

Swinburne University of Technology, rjlewinski@outlook.com

Danielle Polderman

Swinburne University of Technology, 9994459@student.swin.edu.au

Paul Tkalcevic

Swinburne University of Technology, 2106876@student.swin.edu.au

Follow this and additional works at: https://commons.erau.edu/ijaaa

Part of the Management and Operations Commons

\section{Scholarly Commons Citation}

Gao, Y., Carrigg, M., Lewinski, R., Polderman, D., \& Tkalcevic, P. (2018). The perceived value of frequent flyer program benefits among Australian travelers. International Journal of Aviation, Aeronautics, and Aerospace, 5(3). https://doi.org/10.15394/ijaaa.2018.1249

This Article is brought to you for free and open access by the Journals at Scholarly Commons. It has been accepted for inclusion in International Journal of Aviation, Aeronautics, and Aerospace by an authorized administrator of Scholarly Commons. For more information, please contact commons@erau.edu. 
Ever since the airline industry started to embrace the loyalty programs in the early 1980s, almost all major carriers have set up their frequent flyer programs with the aim of enhancing customer loyalty. In the last four decades, frequent flyer programs of airlines have gone through several stages of revolutionary changes, from distance-based rewarding to revenue-based rewarding, from being part of airline operations to coalition programs that coexist and collaborate with airline operations. The airline industry has witnessed the dramatic growth of frequent flyer programs, with some programs now boasting over 70 million members (Ernst \& Young Advisory, 2014). It is not news anymore that some frequent flyer programs are now contributing a significant share to the total revenue of airlines (Qantas Airways, 2016).

Frequent flyer programs are becoming a part of the daily life in many countries, primarily due to the increasingly diversified commercial cooperation between airlines and their business partners, including banks, car rental companies, hotels, retailers, grocery stores, service stations, and other entities. In recognition of the popularity of frequent flyer programs, researchers around the globe have paid much attention to this lucrative business. Numerous studies have been done in recent years to address frequent flyer programs, or more generically loyalty programs, from distinctive perspectives.

Regarding the effect of frequent fly programs on customer loyalty, Whyte (2003a, 2003b), through studying Australian frequent business travelers, agree that frequent flyer schemes do encourage repeat purchase but do not agree that repeat purchase is a measure of loyalty. He expresses concerns over airlines' growing liabilities created by unredeemed frequent flyer points and increasing cost of administering frequent flyer schemes. The study argues that frequent flyer programs create only "spurious loyalty" and they are not sustainable competitive strategies.

In retail, researchers typically use "share-of-wallet" to measure behavior loyalty. Leenheer, van Heerde, Bijmolt, and Smidts (2007) collected purchase behavior of 1,909 Dutch households in supermarkets during July 1998 - July 2000. Their study found "a significant positive yet small effect of loyalty program membership on share-of-wallet.” Interestingly, they argue that selfselecting members are already loyal to the store at the time of enrolment. Therefore, being a member of the loyalty program mostly allows a customer to enjoy more savings or collect more rewards instead of increasing their loyalties. Similar conclusions have been made by Liu (2007) on consumers who are already heavy buyers before they become or just become members of loyalty programs. This group of consumers mostly enjoy the benefits of the loyalty program without becoming more loyal. However, for light or moderate consumers, the participation of loyalty programs would positively affect their share-of-wallet, especially in the first three months of joining (Liu, 2007). 
Frequent flyer programs have been widely regarded as an essential factor influencing air passengers' choice of airlines in different countries. In a study that addresses the demand for air services of Singapore Airlines (SIA), membership of Krisflyer, the frequent flyer program of Singapore Airlines, is found to be a significant factor in determining an individual's choice of Singapore airlines, though that effect is not as strong as the convenience of flight schedules (Chin, 2002). In Sweden, Carlsson and Löfgren (2006) find that both perceived service quality differences and frequent flyer programs are contributing to the cost of switching from one airline to another, and such switching cost can be substantial. In Korea, Park (2010) confirms that frequent flyer programs have direct and indirect effects on pricing, passenger satisfaction, airline image, and airline selection through a passenger survey conducted at Incheon International airport. In Spain, a survey is administered for passengers traveling between Gran Canaria and Madrid, and analysis of survey responses finds that membership of frequent flyer program, as well as a source of payment for the airfare, would affect the willingness to pay for various airline services (Martín, Román, \& Espino, 2011). Moreover, in the United States, Seelhorst and Liu (2015) identify that frequent flyer programs membership, in particular, elite membership, play a significant role in American passengers' choice of airlines, using both Multinomial Logit Model (MNL) and Latent Class Model (LCM).

The effect of frequent flyer programs on pricing and competition of airlines is another interesting research area as it relates to the overall welfare of passengers. Ramón and Adina (2005) argue that frequent flyer programs are pro-competition in highly competitive markets by generating a lower average price and thus creating higher consumer surplus. However, such effect could be reversed when the market is dominated by a small number of airlines and when airlines are restricted to use specific loyalty program designs involving low commitment value for consumers such as lump-sum discounts. On the contrary, Escobari (2011) find that frequent flyer programs affects the entire price distribution, though the effect is more evident on the lower end. Meanwhile, Escobari (2011) partially supports Ramón and Adina (2005) in their argument over the role of airport dominance: When the airport is dominated by a small number of airlines, the effect of frequent flyer programs on pricing becomes weaker in that it only increases the premium on lower end fares. However, this is not supported by another study conducted in Chile, where researchers find that the frequent flyer program of the dominant airline, LAN, creates a fare premium of $35 \%$ on business trips in a market with less competition (Agostini, Inostroza, \& Willington, 2015). It seems from available literature that no consensus has been reached in the effect of frequent flyer programs on pricing and competition.

Loyalty programs including frequent flyer programs offer various benefits to retain and to grow customer bases. Mimouni-Chaabane and Volle 
(2010) identify five types of perceived benefits of loyalty programs: monetary savings, exploration, entertainment, recognition, and social benefits. The five dimensions have different impacts on passengers' satisfaction with the program, loyalty to the program, and perceived relationship investment of the firm. Other studies group perceived benefits of frequent flyer programs into three different underlying dimensions, name recognition, convenience, and exploration (Terblanche, 2015).

The perceived value and perceived loyalty vary according to the purchase orientation of passengers (Lars, 2013). Intrinsic rewards motivate customers to obtain a benefit they want and would lead to purchase behavior and loyalty, while extrinsic rewards would not influence loyalty. Therefore, more diverse rewards, especially non-monetary benefits, should be offered by frequent flyer programs so that consumers of different motivations and purchase orientations could be better motivated (Lars, 2013). This is supported by Kreis and Mafael (2014) who find that loyalty programs targeting common consumer motives provide a higher level of perceived values.

While there is a plethora of literature on the perceived benefits of frequent flyer programs, most analysis focus on the categorization of these benefits and their overall impacts. Very few studies have addressed the distinction of benefits of different programs, nor have they done much work in quantifying such benefits. One of the few attempts has been completed by Basumallick, Ozdaryal, and Madamba-Brown (2013). Their study outlines a method to estimate the perceived value of a mile, which varies significantly dependent on values of redeemed rewards.

Addressing frequent flyer program benefits in a quantitative approach has its practical implications. Some low-cost carriers offer specific benefits for purchase, which are traditionally associated with frequent flyer programs of legacy carriers. By paying extra in addition to basic seats, passengers will access benefits such as more luggage allowance, point accumulation, and airport lounge access (Jetstar Airways, 2017). On the other hand, some traditionally full-service carriers recently started to offer no-frills products in their main cabin. If passengers opt to pay for the lowest airfare, they will have lower or no luggage allowance, no point accumulation, and board lastly (United Airlines, 2017). Valuation of frequent flyer program benefits could provide a basis for the pricing of extra benefits offered by low-cost carriers, or could provide a reference for full-service carriers to price the newly added no-frills class in the main cabin. Therefore, this study aimed to answer the following three research questions:

1). Do travelers value extra benefits provided by low-cost carriers in addition to basic seats on the flight? 
2). Do travelers value premium benefits offered by full-service carriers that are exclusive to elite frequent flyers?

$3)$. Is the perceived value of such benefits correlated with the length of the journey, purposes of traveling, the frequency of traveling, or frequent flyer program status?

It was anticipated that the present study will be able to help expand the current literature on the perceived value of frequent flyer programs. Results of the present study could potentially be used as references by revenue management and frequent flyer programs of airlines to further increase the yield from ticket sales.

\section{Method}

The present study used a self-constructed scenario-based questionnaire to collect responses of participants on perceived values of extra benefits and premium benefits offered by airlines. Extra benefits were defined as additional services that are usually provided by low-cost carriers for passengers who are willing to pay for on top of the basic price. Typical extra benefits include higher luggage allowance, onboard meals, and advanced seat selection. Premium benefits refer to services that are exclusively available to passengers with elite airline status or traveling in premium classes (business or first class). Typical premium benefits include preferred seating, priority check-in and boarding, and airport lounge access, in addition to extra benefits.

The questionnaire consisted of three parts. Part I included six demographic questions which were designed to provide a basic understanding of the survey participants. Part II and III were designed to measure perceived values of extra benefits and premium benefits, respectively. See Appendix for the survey questionnaire used by this study.

Part II of the questionnaire used three domestic Australian itineraries and three international itineraries with Melbourne as the origin. Two ticket options were provided for each itinerary. Option 1 represented a typical basic ticket sold by a low-cost carrier, covering the only seat and limited carry-on luggage allowance. Option 2 simulated the optional added-on package, termed as extra benefits, provided by low-cost carriers during online ticket booking. A reference price was provided for Option 1 of each itinerary, and survey participants were asked to name their highest offers for ticket Option 2.

Similarly, Part III of the questionnaire provides the same itineraries as in Part II. Two ticket options were provided for each itinerary, with Option 1 being the basic option. What is different in this part is that Option 2 is meant to represent premium benefits that are exclusively available to frequent flyers with elite status or traveling in premium cabins. Again, reference prices were 
provided for Option 1 of all itineraries, and survey participants are asked to name their highest offers for ticket Option 2.

Regarding the sample itineraries used in the questionnaire, a total number of six routes originating from Melbourne were selected, with three being domestic and other three being international. The intention of this selection was to cover short-haul, medium-haul, and long-haul scenarios for both domestic and international operations. The distance and typical flight times of all itineraries were provided for survey participants. See Table 1 for details of itineraries.

Table 1

Itineraries used in the survey questionnaire

\begin{tabular}{llll}
\hline & Itinerary & Distance & Flight Time \\
\hline \multirow{4}{*}{ Domestic } & Melbourne-Sydney & $706 \mathrm{~km}$ & $1: 25$ \\
& Melbourne-Brisbane & $1,379 \mathrm{~km}$ & $2: 10$ \\
& Melbourne-Perth & $2,706 \mathrm{~km}$ & $4: 10$ \\
\hline \multirow{5}{*}{ International } & & \\
& Melbourne-Auckland & $2,644 \mathrm{~km}$ & $3: 30$ \\
& Melbourne-Singapore & $6,025 \mathrm{~km}$ & $8: 00$ \\
& Melbourne-Los Angeles & $12,748 \mathrm{~km}$ & $14: 20$ \\
\hline
\end{tabular}

Data collection of the present study used an online survey provider SurveyMonkey.com. The questionnaire is loaded onto SurveyMonkey, and the link to the survey was shared to potential participants so that they could opt to take the survey. Participants were mainly recruited from two sources. The first group of participants was from "Frequent Flyers Australia," an interest group on Facebook with more than 4,000 members at the time of data collection. Moreover, the second source was a convenience sample of family members, friends, students and acquaintances of the authors.

This study was been approved by the Human Research Ethics Committee of the institution with which the authors are affiliated. Therefore the conduct of this study, especially the data collection, complied with the Australia National Statement on Ethical Conduct in Human Research (2007) (National Health and Medical Research Council, 2015). A consent information statement had been presented to potential participants before they decided to take the survey. Participation of the survey was entirely voluntary and anonymous. There was no penalty of any kind to refuse or to withdraw from the survey before completing all the questions. Participants needed to agree with the statement prior to proceeding to the actual survey items.

The survey was open for data collection from 13 September to 4 October 2016. During this period, a total number of 136 complete responses had been 
collected from survey participants. It is impossible to calculate the accurate response rate as it is unknown how many people have received the link to the survey.

\section{Results}

Among the 136 valid responses, most of them were from travelers who primarily fly for leisure in the last 12 months. $21 \%$ of the survey respondents identify themselves as business travelers, and the rest $5 \%$ choose not to disclose or were unable to decide the primary reason for traveling. In terms of the number of trips by air in the last 12 months, besides the six respondents who do not travel at all, there was a good spread of data at different travel frequencies. Assuming most of the participants answer the questionnaire truthfully, then the survey does attract some frequent travelers, who were most likely from the "Frequent Flyer Australia" Facebook group. The frequency of traveling was also indirectly reflected by their frequent flyer program status. More than 40 participants have achieved Gold status or above with at least one frequent flyer program. Meanwhile, 74 responses indicate that they either were not members of any frequent flyer programs or were just basic members at the time of the survey. See Figure 1-3 for details.

When linking reasons for travel and frequent flyer program status together for analysis, it was evident in responses that elite travelers (Gold and Platinum members) fly more for business while basic members and nonmembers fly more for leisure purposes. When the number of trips made in the last 12 months was viewed along with reasons for travel, it can be seen that frequent travelers fly more for business reasons while leisure travelers dominate the infrequent flyer group. See Figure 4 and 5 for details.

In terms of participants' pricing of extra benefits and premium benefits, a general observation of survey responses was that higher prices were offered to routes of longer distances (Figure 6). Moreover, what's more interesting was that price premiums over basic options offered by participants for both extra benefits and premium benefits mostly increase with distances of routes as well, except Melbourne-Perth and Melbourne-Auckland. For instance, participants indicate that they were willing to pay an additional \$52.52 on the MEL-SYD route to enjoy extra benefits over basic options provided by airlines, and that offer grows to $\$ 212.91$ on average on the MEL-LAX route. See Table 2 for details of responses. 


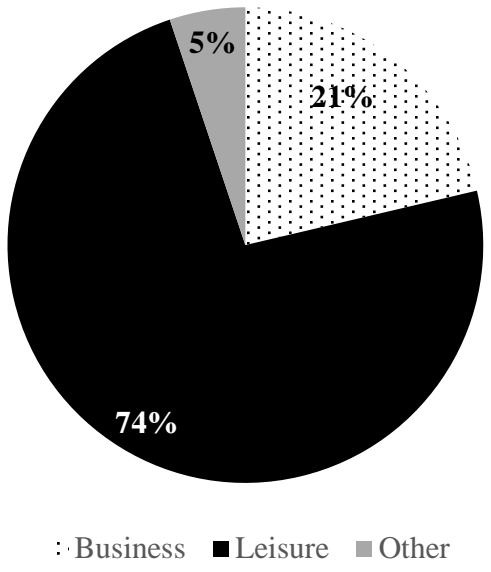

Figure 1. Primary reasons for travel in the last 12 months

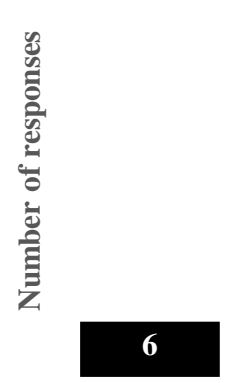

$0-0$

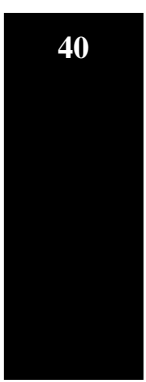

1 to 5

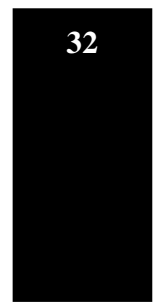

6 to 10

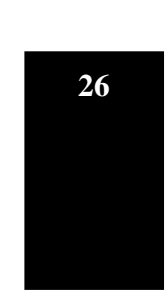

11 to 20

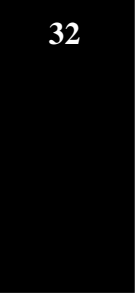

$20+$

Number of trips

Figure 2. Number of trips by air in the last 12 months

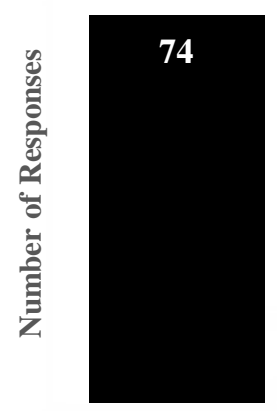

Nill/Bronze

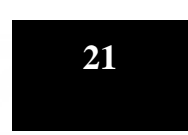

Silver

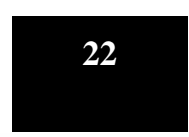

Gold

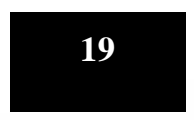

Platinum or above

Figure 3. Higher frequent flyer program status ever achieved 


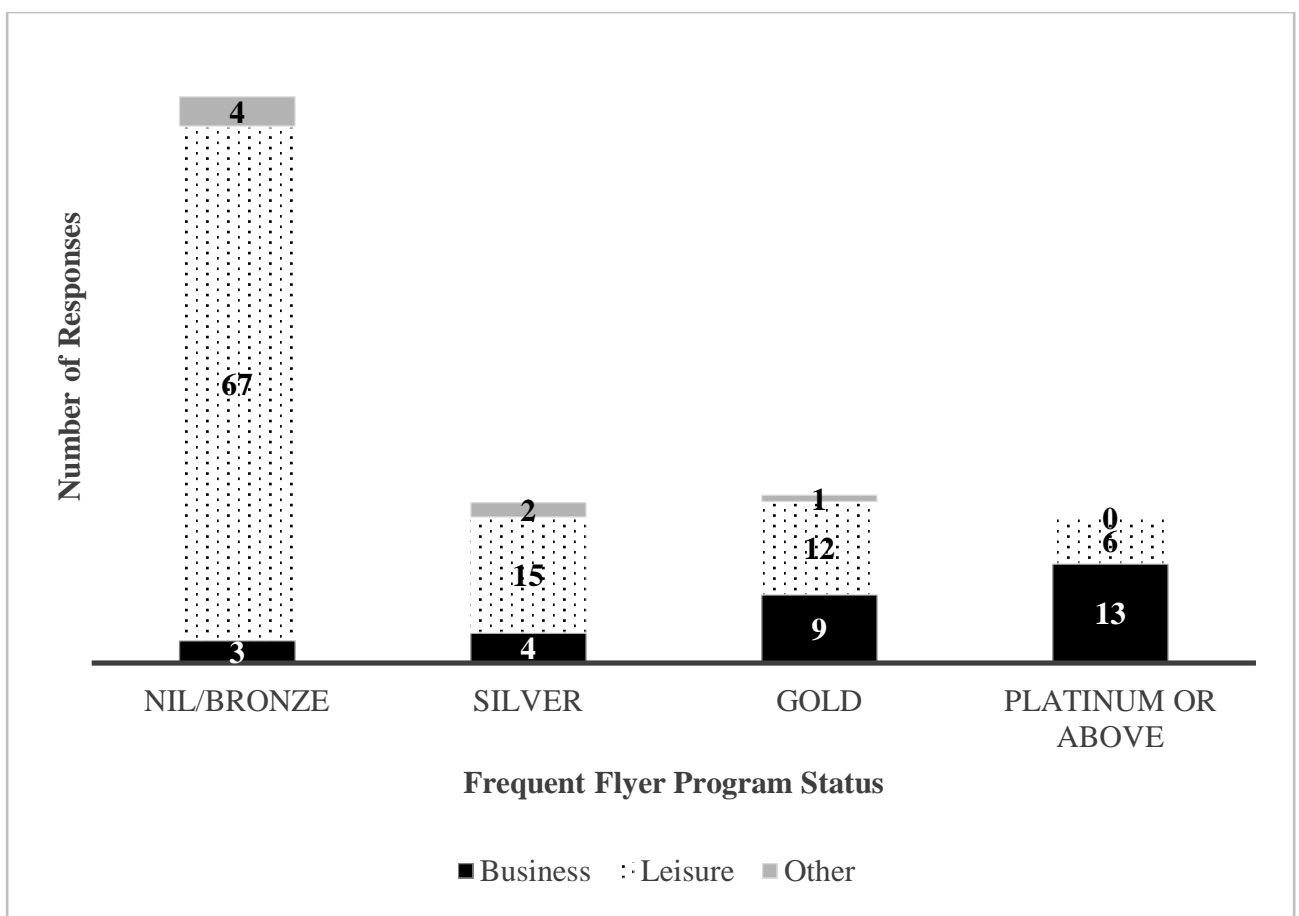

Figure 4. Frequent flyer program status and reasons for travel

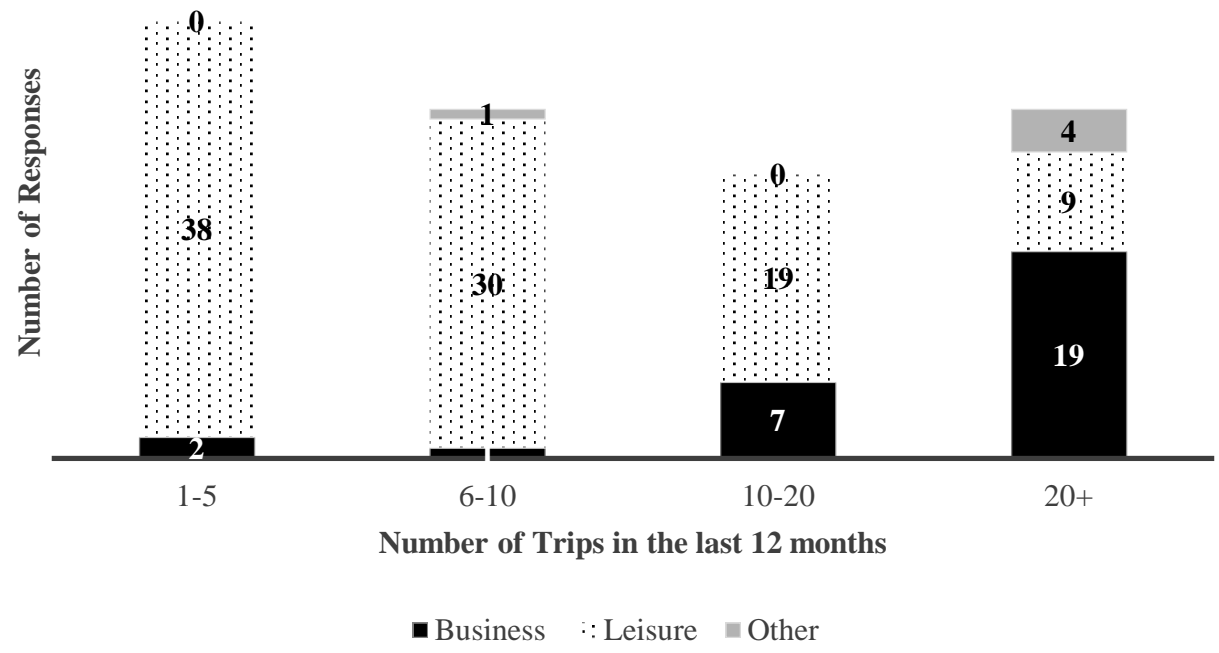

Figure 5. Number of trips and reasons for travel 


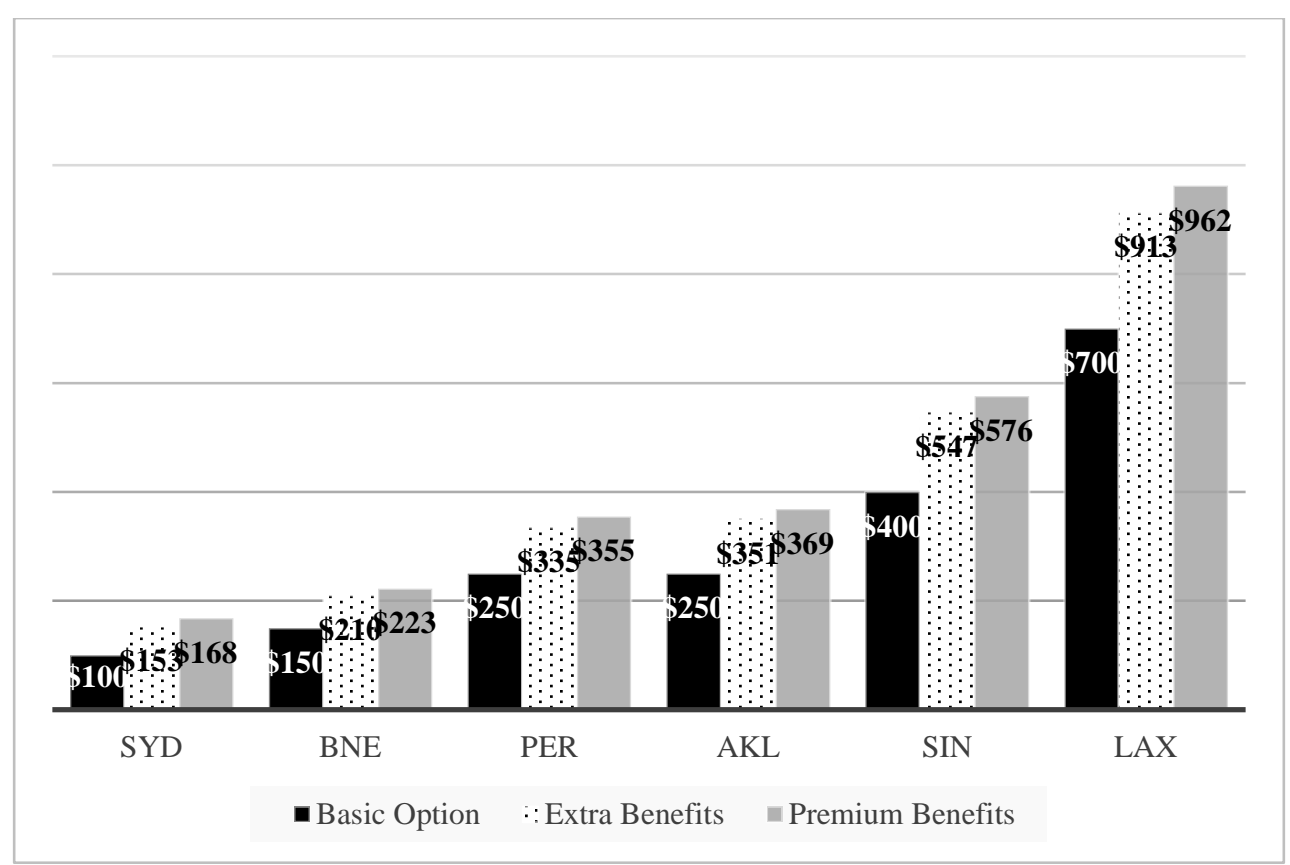

Figure 6. Responses on extra benefits and premium benefits pricing

Table 2

Descriptive statistics of responses on all routes

\begin{tabular}{lllcccc}
\hline & Route & Responses & $\begin{array}{c}\text { Responding } \\
\text { Rate }\end{array}$ & Mean & Std Dev. & $\begin{array}{c}\text { Price } \\
\text { premium } \\
\text { (Compared } \\
\text { with basic } \\
\text { options) }\end{array}$ \\
\hline \multirow{5}{*}{ Extra } & SYD & 133 & $97.80 \%$ & $\$ 152.52$ & $\$ 44.89$ & $\$ 52.52$ \\
& BNE & 131 & $96.30 \%$ & $\$ 210.25$ & $\$ 59.71$ & $\$ 60.25$ \\
& PER & 128 & $94.10 \%$ & $\$ 334.65$ & $\$ 85.60$ & $\$ 84.65$ \\
& AKL & 135 & $99.30 \%$ & $\$ 350.67$ & $\$ 111.53$ & $\$ 100.67$ \\
& SIN & 135 & $99.30 \%$ & $\$ 547.00$ & $\$ 168.69$ & $\$ 147.00$ \\
& LAX & 134 & $98.50 \%$ & $\$ 912.91$ & $\$ 264.67$ & $\$ 212.91$ \\
\hline Premium & SYD & 135 & $99.30 \%$ & $\$ 168.00$ & $\$ 59.67$ & $\$ 68.00$ \\
& BNE & 134 & $98.50 \%$ & $\$ 222.59$ & $\$ 75.04$ & $\$ 72.59$ \\
& PER & 133 & $97.80 \%$ & $\$ 355.11$ & $\$ 104.46$ & $\$ 105.11$ \\
& AKL & 134 & $98.50 \%$ & $\$ 368.81$ & $\$ 118.01$ & $\$ 118.81$ \\
& SIN & 135 & $99.30 \%$ & $\$ 576.33$ & $\$ 179.28$ & $\$ 176.33$ \\
& LAX & 132 & $97.10 \%$ & $\$ 962.11$ & $\$ 284.47$ & $\$ 262.11$ \\
\hline
\end{tabular}


A series of paired $t$-tests were performed to test if offers made by participants for extra benefits were different from offers for premium benefits on the same route. Results of the analysis indicate that all the differences were statistically significant $(p=0.05)$. That means, on all six routes, survey participants were willing to pay a significantly higher price for premium benefits than what they will pay for extra benefits. See Table 3 for a summary of test results.

Table 3

Paired T-test on responses between extra benefits and premium benefits of all routes

\begin{tabular}{lllllll}
\hline Route & $\begin{array}{l}\text { Mean } \\
\text { Response } \\
\text { Difference }\end{array}$ & Std. Dev. & $\begin{array}{l}\text { Std. Error } \\
\text { Mean }\end{array}$ & t & df & $\begin{array}{l}\text { Significance } \\
\text { (2-tailed) }\end{array}$ \\
\hline SYD* $^{*}$ & $-\$ 15.75$ & $\$ 36.39$ & $\$ 3.16$ & -4.992 & 132 & .000 \\
BNE* $^{*}$ & $-\$ 13.39$ & $\$ 39.99$ & $\$ 3.49$ & -3.832 & 130 & .000 \\
PER* $^{*}$ & $-\$ 23.16$ & $\$ 52.84$ & $\$ 4.67$ & -4.959 & 127 & .000 \\
AKL* $^{*}$ & $-\$ 17.76$ & $\$ 75.16$ & $\$ 6.49$ & -2.736 & 133 & 0.007 \\
SIN* $^{*}$ & $-\$ 32.54$ & $\$ 101.59$ & $\$ 8.78$ & -3.707 & 133 & .000 \\
LAX* & $-\$ 50.90$ & $\$ 109.42$ & $\$ 9.52$ & -5.345 & 131 & .000 \\
\hline
\end{tabular}

Note: * means the difference between responses on extra benefits and premium benefits of that particular route is significant $(p=.05)$

A series of one-way ANOVA have been conducted on responses to each route to see if participants of different incomes, reasons for traveling, number of trips made in the last 12 months, and frequent flyer program status would offer differently for extra benefits and premium benefits. However, income, the primary reason for traveling, and number of trips made in the previous 12 months were not found to be significant $(p=0.05)$. The only significant factor that was found to be frequent flyer program status on the MEL-LAX route for both extra benefits and premium benefits. However, this particular factor was not significant on five other routes. See Table 4 for $p$ values of one-way ANOVA tests.

A post hoc Least Significant Difference (LSD) test was subsequently performed to the MEL-LAX route to enable a more thorough understanding of how frequent flyer program status affect the perceived value of benefits on this route. This has been done on responses to extra benefits and premium benefits respectively. It was found that Platinum members were the most generous of all four groups of travelers. They attach a significantly higher value to extra benefits on this long-haul international route than other flyers. Regarding premium benefits, Platinum members were also willing to pay more than nonmembers, members of no status, or Gold members. Notably, Silver members 
make higher offers than Gold members on both extra benefits and premium benefits, though such differences were not statistically significant. See Table 5 and 6 for details of LSD results.

Table 4

Summary of one-way ANOVA ( $p$ values) of different factors on individual route

\begin{tabular}{|c|c|c|c|c|c|c|c|c|c|c|c|c|}
\hline \multirow{2}{*}{ Factors } & \multicolumn{6}{|c|}{ Extra Benefits } & \multicolumn{6}{|c|}{ Premium Benefits } \\
\hline & SYD & BNE & PER & AKL & SIN & LAX & SYD & BNE & PER & AKL & SIN & LAX \\
\hline Income & 0.34 & 0.46 & 0.12 & 0.28 & 0.07 & 0.14 & 0.97 & 0.90 & 0.23 & 0.54 & 0.22 & 0.349 \\
\hline $\begin{array}{c}\text { Purpose } \\
\text { of } \\
\text { Travel }\end{array}$ & 0.61 & 0.55 & 0.17 & 0.46 & 0.59 & 0.62 & 0.94 & 0.86 & 0.24 & 0.57 & 0.37 & 0.754 \\
\hline $\begin{array}{l}\text { Trips in } \\
\text { the last } \\
12 \\
\text { months }\end{array}$ & 0.954 & 1 & 0.91 & 0.99 & 0.91 & 0.89 & 0.90 & 0.97 & 0.99 & 0.63 & 0.76 & 0.796 \\
\hline $\begin{array}{c}\text { FFP } \\
\text { Status }\end{array}$ & 0.49 & 0.70 & 0.54 & 0.613 & 0.267 & $0.01 *$ & 0.463 & 0.587 & 0.662 & 0.747 & 0.707 & $0.02 *$ \\
\hline
\end{tabular}

Note: * represents the corresponding factor is significant in the one-way ANOVA test of that particular route

Table 5

Least Significant Difference (LSD) results for one-way ANOVA of extra benefits on the $M E L-L A X$ route using frequent flyer program status as a factor

\begin{tabular}{lllllll}
\hline (I) Status & (J) Status & $\begin{array}{l}\text { Mean } \\
\text { Difference }\end{array}$ & $\begin{array}{l}\text { Std. } \\
\text { Error }\end{array}$ & & Sig. & \multicolumn{2}{l}{ 95\% Confidence Interval } \\
\cline { 5 - 7 } & & & & & $\begin{array}{l}\text { Lower } \\
\text { Bound }\end{array}$ & $\begin{array}{l}\text { Upper } \\
\text { Bound }\end{array}$ \\
\hline Nil & Silver & $-\$ 40.38$ & $\$ 64.84$ & 0.54 & $-\$ 168.66$ & $\$ 87.90$ \\
& Gold & $-\$ 6.11$ & $\$ 62.48$ & 0.92 & $-\$ 129.71$ & $\$ 117.50$ \\
& Platinum & $-\$ 217.823^{*}$ & $\$ 67.62$ & 0.00 & $-\$ 351.59$ & $-\$ 84.05$ \\
\hline Silver & Nil & $\$ 40.38$ & $\$ 64.84$ & 0.54 & $-\$ 87.90$ & $\$ 168.66$ \\
& Gold & $\$ 34.27$ & $\$ 79.49$ & 0.67 & $-\$ 122.99$ & $\$ 191.53$ \\
& Platinum & $-\$ 177.44^{*}$ & $\$ 83.59$ & 0.04 & $-\$ 342.82$ & $-\$ 12.07$ \\
\hline Gold & Nil & $\$ 6.11$ & $\$ 62.48$ & 0.92 & $-\$ 117.50$ & $\$ 129.71$ \\
& Silver & $-\$ 34.27$ & $\$ 79.49$ & 0.67 & $-\$ 191.53$ & $\$ 122.99$ \\
& Platinum & $-\$ 211.71^{*}$ & $\$ 81.77$ & 0.01 & $-\$ 373.49$ & $-\$ 49.94$ \\
\hline Platinum & Nil & $\$ 217.82^{*}$ & $\$ 67.62$ & 0.00 & $\$ 84.05$ & $\$ 351.59$ \\
& Silver & $\$ 177.44^{*}$ & $\$ 83.59$ & 0.04 & $\$ 12.07$ & $\$ 342.82$ \\
& Gold & $\$ 211.71^{*}$ & $\$ 81.77$ & 0.01 & $\$ 49.94$ & $\$ 373.49$ \\
\hline
\end{tabular}

Note: * The mean difference is significant at the 0.05 level. 
Table 6.

Least Significant Difference (LSD) results for one-way ANOVA of premium benefits on the $M E L-L A X$ route using frequent flyer program status as a factor

\begin{tabular}{|c|c|c|c|c|c|c|}
\hline \multirow{2}{*}{ (I) Status } & \multirow{2}{*}{ (J) Status } & \multirow{2}{*}{$\begin{array}{l}\text { Mean } \\
\text { Difference (I-J) }\end{array}$} & \multirow{2}{*}{$\begin{array}{l}\text { Std. } \\
\text { Error }\end{array}$} & \multirow{2}{*}{ Sig. } & \multicolumn{2}{|c|}{ 95\% Confidence Interval } \\
\hline & & & & & Lower Bound & Upper Bound \\
\hline \multirow{3}{*}{ Nil } & Silver & $-\$ 62.25$ & $\$ 70.16$ & 0.54 & $-\$ 201.07$ & $\$ 76.57$ \\
\hline & Gold & $\$ 2.34$ & $\$ 67.62$ & 0.92 & $-\$ 131.45$ & $\$ 136.13$ \\
\hline & Platinum & $-\$ 218.69 *$ & $\$ 73.15$ & 0.00 & $-\$ 363.43$ & $-\$ 73.96$ \\
\hline \multirow{3}{*}{ Silver } & Nil & $\$ 62.25$ & $\$ 70.16$ & 0.54 & $-\$ 76.57$ & $\$ 201.07$ \\
\hline & Gold & $\$ 64.59$ & $\$ 85.76$ & 0.67 & $-\$ 105.10$ & $\$ 234.28$ \\
\hline & Platinum & $-\$ 156.44$ & $\$ 90.18$ & 0.04 & $-\$ 334.88$ & $\$ 21.99$ \\
\hline \multirow{3}{*}{ Gold } & Nil & $-\$ 2.34$ & $\$ 67.62$ & 0.92 & $-\$ 136.13$ & $\$ 131.45$ \\
\hline & Silver & $-\$ 64.59$ & $\$ 85.76$ & 0.67 & $-\$ 234.28$ & $\$ 105.10$ \\
\hline & Platinum & $-\$ 221.03^{*}$ & $\$ 88.22$ & 0.01 & $-\$ 395.59$ & $-\$ 46.48$ \\
\hline \multirow{3}{*}{ Platinum } & Nil & $\$ 218.694 *$ & $\$ 73.15$ & 0.00 & $\$ 73.96$ & $\$ 363.43$ \\
\hline & Silver & $\$ 156.44$ & $\$ 90.18$ & 0.04 & $-\$ 21.99$ & $\$ 334.88$ \\
\hline & Gold & \$221.03* & $\$ 88.22$ & 0.01 & $\$ 46.48$ & $\$ 395.59$ \\
\hline
\end{tabular}

Note: * The mean difference is significant at the 0.05 level.

\section{Conclusions}

Since the inception of the no-frills service concept in the airline industry, low-cost carriers represented by Southwest, EasyJet, and Jetstar have gained tremendous momentum and are becoming increasingly popular among the traveling public. Not only has such a trend made air travel more affordable than ever before, but it has also pushed the industry into its current form. Legacy carriers such as Singapore Airlines and Qantas are trying to appeal to premium travelers by offering unparalleled onboard amenities and experience, while lowcost carriers are strengthening their cost advantage to gain even more market shares among price-sensitive travelers. Meanwhile, airlines of both business models are also trying to step into the backyard of each other. Some full-service carriers such as United Airlines recently started to offer Basic Economy, a lowcost equivalent product, in the main cabin. A small number of low-cost carriers such as Jetstar are offering frequent flyer points earning options as part of an add-on package for its customers to generate more revenue.

In recognition of the current industry landscape, results of this study reassure both full service and low-cost carriers that air travelers in general value extra benefits on top of basic seats and limited carry-on luggage allowance. Most survey participants indicate that they were willing to pay more to access additional benefits. The more encouraging result to the airline industry was that the valuation of benefits grows with the distance of route and increases when 
more benefits are being offered in the package. This allows airlines to develop a more dynamic and adaptive pricing scheme to capitalize on customer recognition.

This study could provide a direction for airlines in data mining of travelers' profiles. Before statistical analysis, it was anticipated that income, the primary reason for traveling and traveling frequency would be sensible predictors for benefits valuation. However, none of these factors was found to be statistically significant, which does not support the earlier findings of Long, McMellon, Clark, and Schiffman (2006). The only significant factor was found to be frequent flyer program status. Top tier members were willing to offer the most generous recognition to both extra benefits and premium benefits. It was, however, impossible to distinguish if Platinum members make the highest offer because of their status, or if their willingness to spend more earns them the elite status with airlines. Another interesting finding was that offers made by frequent travelers do not necessarily correlate with their frequent flyer status. For instance, Silver members offer higher than Gold members do, though such a difference was not statistically significant. It still warrants a direction for the airline to investigate further if this spending reversal was due to the quality of data used in this study or if it was caused by more profound motivations.

This study inevitably has its restrictions. First of all, the power of results could be potentially compromised by the relatively small sample size. A more powerful analysis could have been done had the sample size been larger than what was available in this study. Secondly, the way that the questionnaire was presented to participants could bring bias into responses. Six routes were sorted by their lengths and were listed on the same page. This does not replicate the actual booking experience with airlines or travel agents as passengers are only facing one itinerary choice at a time with no available additional referencing prices on the same page. Because of the way how questionnaire was presented, survey participants could intuitively make higher offers to longer routes. However, this potential bias was somehow weakened by the fact that after subtracting the component of basic option price from offers made to each itinerary, the top-up part still correlates positively with the distance of the route. This was a good indication that participants were answering survey questions consciously.

This study has its merit in fulling the gap of current literature about perceived values of frequent flyer programs. It confirms the reasoning of current practices used by both full service and low-cost carriers and points out to airlines of both business models the need to price add-on benefits more dynamically instead of using a flat rate. It was also valuable to loyalty program managers who will be able to further engage top-tier members and not cause unintended aversions among mid-tier members through precise marketing and promotions. 
Future studies on the perceived value of frequent flyer program benefits should consider improving data collection to overcome limitations of this study. Instead of displaying all the routes on the same page to participants, researchers could randomly select a subset of sample routes and have different participants respond to different routes. By doing so, it was anticipated that bias caused by questionnaire design could be reduced to a minimum. If a larger sample that represents a more diverse social-economic background could be recruited, the power of the study would be significantly improved. 


\section{References}

Agostini, C. A., Inostroza, D., \& Willington, M. (2015). Price effects of airlines frequent flyer programs: The case of the dominant firm in Chile. Transportation Research Part A: Policy and Practice, 78, 283297. doi: https://doi.org/10.1016/j.tra.2015.05.011

Basumallick, D., Ozdaryal, B., \& Madamba-Brown, C. (2013). Perceived value of a mile. Journal of Revenue and Pricing Management, 12(1), 8-15. doi: 10.1057/rpm.2012.34

Carlsson, F., \& Löfgren, Å. (2006). Airline choice, switching costs and frequent flyer programmes. Applied Economics, 38(13), 1469-1475. doi: 10.1080/00036840500419608

Chin, A. T. H. (2002). Impact of frequent flyer programs on the demand for air travel. Journal of Air Transportation, 7(2), 53-86.

Ernst \& Young Advisory. (2014). Frequent flyer program: Ready for take-off. Retrieved from http://www.ey.com/Publication/vwLUAssets/etude-eysur-les-programmes-de-fidelite-des-compagniesaeriennes/\$FILE/etude-ey-sur-les-programmes-de-fidelite-descompagnies-aeriennes.pdf

Escobari, D. (2011). Frequent flyer programs premium and the role of airport dominance. Applied Economics Letters, 18(16), 1565-1569. doi: $10.1080 / 13504851.2010 .548780$

Jetstar Airways. (2017). Economy bundles - what's included. Retrieved from http://www.jetstar.com/au/en/help/articles/economy-bundles-whatsincluded

Kreis, H., \& Mafael, A. (2014). The influence of customer loyalty program design on the relationship between customer motives and value perception. Journal of Retailing and Consumer Services, 21(4), 590600. doi: https://doi.org/10.1016/j.jretconser.2014.04.006

Lars, M.-W. (2013). The impact of reward personalisation on frequent flyer programmes ' perceived value and loyalty. Journal of Services Marketing, 27(3), 183-194. doi: 10.1108/08876041311330681 
Leenheer, J., van Heerde, H. J., Bijmolt, T. H. A., \& Smidts, A. (2007). Do loyalty programs really enhance behavioral loyalty? An empirical analysis accounting for self-selecting members. International Journal of Research in Marketing, 24(1), 31-47. doi: https://doi.org/10.1016/j.ijresmar.2006.10.005

Liu, Y. (2007). The long-term impact of loyalty programs on consumer purchase behavior and loyalty. Journal of Marketing, 71(4), 19-35. doi: $10.1509 / j m k g .71 .4 .19$

Long, M. M., McMellon, C., Clark, S. D., \& Schiffman, L. G. (2006). Building relationships with business and leisure flyers. Services Marketing Quarterly, 28(1), 1-17. doi:10.1300/J396v28n01_01

Martín, J. C., Román, C., \& Espino, R. (2011). Evaluating frequent flyer programs from the air passengers' perspective. Journal of Air Transport Management, 17(6), 364-368. doi: https://doi.org/10.1016/j.jairtraman.2011.02.008

Mimouni-Chaabane, A., \& Volle, P. (2010). Perceived benefits of loyalty programs: Scale development and implications for relational strategies. Journal of Business Research, 63(1), 32-37. doi: https://doi.org/10.1016/j.jbusres.2009.01.008

National Health and Medical Research Council. (2015). National statement on ethical conduct in human research (2007) - Updated May 2015.

Retrieved from https://www.nhmrc.gov.au/guidelines-publications/e72

Park, J.-W. (2010). The effect of frequent flyer programs: A case study of the Korean airline industry. Journal of Air Transport Management, 16(5), 287-288. doi: https://doi.org/10.1016/j.jairtraman.2010.02.007

Qantas Airways. (2016). New horizons: Qantas annual report 2016. Retrieved from https://www.qantas.com.au/infodetail/about/corporateGovernance/201 6AnnualReport.pdf

Ramón, C., \& Adina, C. (2005). Are loyalty-rewarding pricing schemes anticompetitive? Retrieved from https://ideas.repec.org/p/bge/wpaper/228.html

Seelhorst, M., \& Liu, Y. (2015). Latent air travel preferences: Understanding the role of frequent flyer programs on itinerary choice. Transportation Research Part A: Policy and Practice, 80, 49-61. doi: https://doi.org/10.1016/j.tra.2015.07.007 
Terblanche, N. S. (2015). Customers' perceived benefits of a frequent-flyer program. Journal of Travel \& Tourism Marketing, 32(3), 199-210. doi: 10.1080/10548408.2014.895694

United Airlines. (2017). Basic Economy. Retrieved from https://www.united.com/web/en-US/content/travel/inflight/basiceconomy.aspx

Whyte, R. (2003a). Frequent flyer programmes: Is it a relationship, or do the schemes create spurious loyalty? Journal of Targeting, Measurement and Analysis for Marketing, 12(3), 269-280. doi:10.1057/palgrave.jt.5740114

Whyte, R. (2003b). Loyalty marketing and frequent flyer programmes: Attitudes and attributes of corporate travellers. Journal of Vacation Marketing, 9(1), 17-34. doi:doi:10.1177/135676670200900102 


\section{Appendix}

\section{Survey Questionnaire}

\section{Part I: Demographic Questions}

1. Your age?
A. $18-25$
B. $26-35$
C. $36-45$
D. $46-59$
E. $60+$
F. Prefer not to disclose

2. What's your annual income (pre-tax) in the 2015-2016 financial year?
A. $\$ 0-\$ 37,000$
B. $\$ 37,001-\$ 80,000$ C. $\$ 80,001-\$ 180,000$
D. $\$ 180,000+$
F. Prefer not to disclose

3. In the last 12 months, you travelled mostly for:
A. Business
B. Leisure
C. Other, please specify

4. How many trips by air did you take in last 12 months?
A. 0
B. 1-5
C. 6-10
D. $10-20$
E. $20+$

5. How many Frequent Flyer Programs are you a member of:
A. 0
B. 1
C. 2
D. 3
E. 4 or more

6. What is the highest elite Status you have ever achieved with any airline frequent flyer program?
A. Nil
B. Silver or equivalent
C. Gold or equivalent
D. Platinum (equivalent) or above 


\section{Part II: Value of extra benefits}

For each of the following itineraries (one-way) below, there are two options of travelling in economy class. Option 1 covers the very basics, which include the seat and 7-kg carry-on luggage. Option 2 provides additional benefits. The price of Option 1 is listed below. Please indicate what's the highest price you are willing to pay to travel Option 2.
1. Seat
2. 7-kg Carry- on
3. Earning points
4. In-flight Meal
1. Seat
2. 7-kg
5. 23-kg check- in
Carry-
6. Advanced
on seat selection

\begin{tabular}{|l|l|l|l|l|}
\hline Itinerary & Distance & $\begin{array}{l}\text { Flight } \\
\text { Time }\end{array}$ & $\begin{array}{l}\text { Option 1 } \\
\text { (Advertised } \\
\text { price) }\end{array}$ & $\begin{array}{l}\text { Option 2 } \\
\text { (Your highest offer) }\end{array}$ \\
\hline $\begin{array}{l}\text { Melbourne- } \\
\text { Sydney }\end{array}$ & $706 \mathrm{~km}$ & $1: 25$ & $\$ 100$ & $\$$ \\
\hline $\begin{array}{l}\text { Melbourne- } \\
\text { Brisbane }\end{array}$ & $\begin{array}{l}1,379 \\
\mathrm{~km}\end{array}$ & $2: 10$ & $\$ 150$ & $\$$ \\
\hline $\begin{array}{l}\text { Melbourne- } \\
\text { Perth }\end{array}$ & $\begin{array}{l}2,706 \\
\mathrm{~km}\end{array}$ & $4: 10$ & $\$ 250$ & $\$$ \\
\hline
\end{tabular}

\begin{tabular}{|l|l|l|l|l|}
\hline $\begin{array}{l}\text { Melbourne- } \\
\text { Auckland }\end{array}$ & $\begin{array}{l}2,644 \\
\mathrm{~km}\end{array}$ & $3: 30$ & $\$ 250$ & $\$$ \\
\hline $\begin{array}{l}\text { Melbourne- } \\
\text { Singapore }\end{array}$ & $\begin{array}{l}6,025 \\
\mathrm{~km}\end{array}$ & $8: 00$ & $\$ 400$ & $\$$ \\
\hline $\begin{array}{l}\text { Melbourne- } \\
\text { Los Angeles }\end{array}$ & $\begin{array}{l}12,748 \\
\mathrm{~km}\end{array}$ & $14: 20$ & $\$ 700$ & $\$$ \\
\hline
\end{tabular}




\section{Part III: Value of premium benefits}

For each of the following itineraries (one-way) below, there are two options of travelling in economy class. Option 1 covers the very basics, which include the seat and 7-kg carry-on luggage. Option 2 provides additional benefits available to premium frequent flyers. The price of Option 1 is listed below. Please indicate what's the highest price you are willing to pay to travel Option 2.

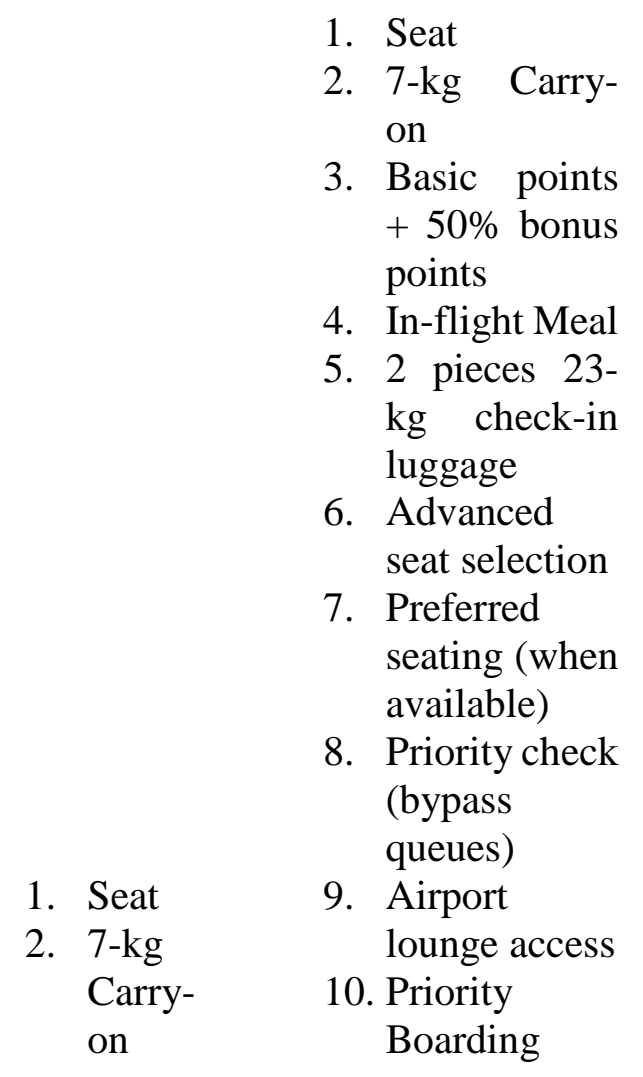

\begin{tabular}{|l|l|l|l|l|}
\hline Itinerary & Distance & $\begin{array}{l}\text { Flight } \\
\text { Time }\end{array}$ & $\begin{array}{l}\text { Option 1 } \\
\text { (Advertised } \\
\text { price) }\end{array}$ & $\begin{array}{l}\text { Option 2 } \\
\text { (Your highest offer) }\end{array}$ \\
\hline $\begin{array}{l}\text { Melbourne- } \\
\text { Sydney }\end{array}$ & $706 \mathrm{~km}$ & $1: 25$ & $\$ 100$ & $\$$ \\
\hline $\begin{array}{l}\text { Melbourne- } \\
\text { Brisbane }\end{array}$ & $1,379 \mathrm{~km}$ & $2: 10$ & $\$ 150$ & $\$$ \\
\hline $\begin{array}{l}\text { Melbourne- } \\
\text { Perth }\end{array}$ & $2,706 \mathrm{~km}$ & $4: 10$ & $\$ 250$ & $\$$ \\
\hline
\end{tabular}

\begin{tabular}{|l|l|l|l|l|}
\hline $\begin{array}{l}\text { Melbourne- } \\
\text { Auckland }\end{array}$ & $2,644 \mathrm{~km}$ & $3: 30$ & $\$ 250$ & $\$$ \\
\hline $\begin{array}{l}\text { Melbourne- } \\
\text { Singapore }\end{array}$ & $6,025 \mathrm{~km}$ & $8: 00$ & $\$ 400$ & $\$$ \\
\hline $\begin{array}{l}\text { Melbourne- } \\
\text { Los Angeles }\end{array}$ & $\begin{array}{l}12,748 \\
\mathrm{~km}\end{array}$ & $14: 20$ & $\mathbf{\$ 7 0 0}$ & $\mathbf{\$}$ \\
\hline
\end{tabular}

